\title{
The Adherence to Fixed-Dose Combination Antiretroviral Therapy and Viral Load in HIV Patients
}

\author{
Kepatuhan terhadap Terapi Antiretroviral Kombinasi Dosis Tetap dan Viral Load pada Pasien HIV
}

\author{
Salma Auliannissa ${ }^{1 *}$, Nurfitri Bustamam ${ }^{1}$, Sri Rahayu Ningsih ${ }^{2}$ \\ ${ }^{1}$ Faculty of Medicine, Universitas Pembangunan Nasional Veteran Jakarta, Jalan RS. Fatmawati Raya, Pondok Labu, \\ Cilandak, Depok City, West Java, Indonesia. \\ 2 Faculty of Medicine, Gunadarma University, Jalan Margonda Raya No.100, Pondok Cina, Kecamatan Beji, Depok City, \\ West Java, Indonesia.
}

DATA OF ARTICLE:

Received: 5 Mar 2019

Reviewed: 16 Apr 2019

Revised: 12 Oct 2019

Accepted: 25 Nov 2019

*CORRESPONDENCE:

acacialeaf24@gmail.com

DOI:

10.18196/mm.200137

TYPE OF ARTICLE:

Research

\begin{abstract}
Antiretroviral fixed-dose combination (FDC ARV) has been used in HIV patient therapy. The therapy is recommended to be monitored using a viral load (VL), reflecting the amount of HIV in the blood. Since 2015, the VL testing has been carried out at Pengayoman Cipinang Hospital. However, the evaluation of adherence to the FDC antiretroviral therapy on VL has never been conducted. This study aims to determine the relationship between the adherence level to the FDC ARVs and VL at Pengayoman Cipinang Hospital in 2015-2018. The study used a cross-sectional design and a random sampling technique. The sample size was 70, and data generated from the medical record. Kruskal Wallis test showed no differences in the level of adherence in the group based on gender, education level, marital status, employment status, and the risk factor for HIV. However, there was a significant difference in the age group. Cross-tab data showed virological failure (VL> 400 copies $/ \mathrm{ml}$ ) was found in $1.8 \%$ of patients with good adherence, $75 \%$ of patients with moderate adherence, and $100 \%$ of patients with poor adherence. The Chi-square test showed a significant relationship between adherence to FDC ARV and VL $(\mathrm{p}=0.000)$. It can be concluded that there was a significant relationship between the level of adherence in taking ARV FDC and viral load.
\end{abstract}

Keywords: Adherence; Antiretroviral, Fixed-dose combination; HIV; Viral load

Abstrak: Kombinasi dosis tetap antiretroviral (FDC ARV) telah digunakan dalam terapi pasien HIV. Terapi ini direkomendasikan untuk dipantau menggunakan viral load (VL), yang mencerminkan jumlah HIV dalam darah. Sejak 2015, pengujian VL telah dilakukan di Rumah Sakit Pengayoman Cipinang. Namun, evaluasi kepatuhan terhadap terapi antiretroviral FDC pada VL belum pernah dilakukan. Penelitian ini bertujuan untuk mengetahui hubungan antara tingkat kepatuhan terhadap ARV FDC dan VL di Rumah Sakit Pengayoman Cipinang pada 2015-2018. Penelitian ini menggunakan desain crosssectional dan teknik pengambilan sampel acak. Ukuran sampel adalah 70, dan data didapatkan dari rekam medis. Tes Kruskal Wallis menunjukkan tidak ada perbedaan tingkat kepatuhan berdasarkan jenis kelamin, tingkat pendidikan, status perkawinan, status pekerjaan, dan faktor risiko untuk HIV. Namun, ada perbedaan signifikan kepatuhan pada kelompok umur. Data lintas-tab menunjukkan kegagalan virologi (VL> 400) ditemukan pada 1,8\% pasien dengan kepatuhan yang baik, 75\% pasien dengan kepatuhan sedang, dan 100\% pasien dengan kepatuhan buruk. Uji Chi-square menunjukkan hubungan yang signifikan antara kepatuhan terhadap ARV FDC dan VL ( $p=0,000)$. Dapat disimpulkan bahwa ada hubungan yang signifikan antara tingkat kepatuhan dalam mengambil ARV FDC dan viral load. 


\section{INTRODUCTION}

Based on data from the World Health Organization in 2017, ${ }^{1}$ there are 36.9 million people infected with the Human Immunodeficiency Virus (HIV), where $0.8 \%$ of them are between $15-49$ years old. In Indonesia, the number of new cases of HIV infection continues to rise. Based on the report from January-March in 2017, there were 10,376 HIVinfected people with a cumulative amount of 242 699 people. Jakarta is the province which ranks first with a total of 46.758 HIV-infected people. ${ }^{1}$

Human Immunodeficiency Virus is a retrovirus that infects CD4 T cells and macrophages, which are vital components of the immune system. People living with HIV/AIDS (PLWHA) have a weak immune system that they are likely to be susceptible to opportunistic infections. Therefore, PLWHA must take antiretroviral drugs (ARVs) to maintain their immune system. It is required to have a high level of adherence in taking antiretroviral drugs to have good virological suppression. Adherence is defined as routinely taking drugs based on medical prescriptions. Adherence to taking ARV drugs is the most important factor in reducing the number of HIV viruses. The prolonged stable suppression of the amount of virus aims to keep the body's immune at a high level. ${ }^{2}$ The result shows that to achieve optimal levels of viral suppression, at least $95 \%$ of all doses must be fulfilled. ${ }^{3}$

Based on the result, it reveals that the simpler the ARV drug regimen is, the higher the level of the patients' adherence in taking ARV drugs will be. ${ }^{4}$ Since 2012, Pengayoman Cipinang Hospital has been utilizing antiretroviral fixed-dose combination (FDC) at the first-line. The drug consists of two nucleoside reverse transcriptase inhibitors (NRTIs), such as Tenofovir (TDF) and Lamivudine (3TC) and one nonnucleoside reverse transcriptase inhibitors (NNRTIs), such as Efavirenz (EFV). The combination of these drugs works to inhibit reverse transcriptase so that HIV RNA cannot be transcribed into DNA and entered into the host cell genome. ${ }^{5} \mathrm{HIV}$ patients only need to take FDC ARV once. The treatment using FDC ARVs is the best therapy for HIV patients currently. The main purpose of ARV treatment is to reduce viral load and that the immune status of HIV patients increases, to reduce mortality risk from opportunistic infections, and to reduce the risk of transmission. 5,6

The success of ARV therapy is suggested to be monitored using a viral load that reflects the amount of HIV in the blood. When the test result shows HIV RNA of 20,000 copies/ml, it indicates that there are 10,000 virus particles in every milliliter of blood as each HIV carries two copies of RNA. The result of the test shows that the measurement of viral load on the magnitude of the replication of the virus is better than examining $\mathrm{T}$ CD4 lymphocyte cell levels to predict the progression of HIV infection. Examination of the viral load of HIV is used to determine the effectiveness or failure of antiretroviral therapy. ${ }^{7,8}$

Since 2015, viral load testing has been carried out at Pengayoman Cipinang Hospital using GeneXpert ${ }^{\circledR}$ Dx technology. The tool can automatically extract nucleic acids, perform amplification, and detect nucleic acid sequences using real-time reverse transcriptase-polymerase chain reaction (RT-PCR). ${ }^{9}$ Evaluation of adherence to taking first-line FDC ARV drugs and their effectiveness in suppressing viral load has never been conducted in HIV patients at Pengayoman Cipinang Hospital. Based on this rationale, a study was conducted to determine the relationship between the level of adherence in taking first-line ARV FDC drugs and viral load in HIV patients in Pengayoman Cipinang Hospital

\section{MATERIALS AND METHOD}

This study used a cross-sectional design. The population was patients with HIV who were treated in Pengayoman Cipinang Hospital in 2015-2018 and obtained first-line ARV FDC drugs therapy. Inclusion criteria were such as the second stage of HIV patients receiving first-line ARV FDC therapy (Tenofovir, Lamivudine, and Efavirenz ) for at least one year, outpatients, and above 18 years old. Meanwhile, the exclusion criteria were HIV patients with a background of drug-induced hepatitis. The following formula determines the sample size:

$$
n=\frac{\mathrm{Z}^{2} 1-\propto / 2 \mathrm{P}(1-\mathrm{P}) \mathrm{N}}{d^{2}(N-1)+\mathrm{Z}^{2} 1-\propto / 2 \mathrm{P}(1-\mathrm{P})}
$$

Note:

$\mathrm{n}=$ sample size

$\mathrm{N}=75$ people as the total population

$Z_{1-\alpha / 2}=$ alpha standard deviate, determined with $\alpha 0.05$

$\mathrm{d}=$ absolute accuracy, determined at 0.01

$\mathrm{P}=$ the proportion of HIV patients who adhered to

taking ARV drugs, determined by researchers at 0.5

The result of the calculation of sample size showed 70 data. Data were collected from the medical records written in the HIV treatment overview and antiretroviral therapy at Pengayoman Cipinang Hospital in 2015-2018. Prior to the data collection, the researcher had been granted an 
approval of the ethical review from the Health Research Ethics Commission of the Jakarta Veterans National Development University (Ethical Approval Number: B/1612/IX/2018/KEPK) and a letter of permission from the Head of the Pengayoman Cipinang Hospital. The random sampling technique was used to retrieve the data. This research was conducted at Pengayoman Cipinang Hospital in October 2018.

Research variables were categorized based on previous research. The independent variable in this study was the level of adherence in taking FDC ARV drugs defined as the patients' adherence to taking medication schedules once a day for at least one year of treatment. The result of measuring the level of adherence was divided into three; namely 1) a good level of adherence ( $\geq 95 \%$ ); 2 ) moderate level of adherence (80-95\%); and 3) poor level of adherence $(\leq 80 \%) .{ }^{10}$ Meanwhile, viral load was the dependent variable of this study. It was defined as the amount of virus in the blood and was used as a measurement tool to monitor the success of ARV therapy. In this study, the viral load was divided into two, namely 1 ) successful therapy ( $\leq 400$ copies $/ \mathrm{ml}$ ) and 2 ) failed therapy (>400 copies $/ \mathrm{ml}){ }^{11}$

Data analysis was conducted to obtain a description of the characteristics of the study subjects, the level of adherence in taking FDC ARV drugs to viral load, as well as identifying the relationship between the level of adherence in taking FDC ARV drugs and viral load on the subjects. The Kruskal Wallis test was used to determine whether there is a relationship between subject characteristics and the level of adherence in taking FDC ARV drugs. Furthermore, the cross-tab was utilized to identify the overview of the adherence level of antiretroviral FDC medication on virologic failure (viral load $>400$ copies $/ \mathrm{ml}$ ). As the independent variable (the adherence level in taking FDC ARVs) and the dependent variable (viral load) in this study are categorical variables, the chisquare test was conducted to examine the hypothesis of the study that there is a correlation between the level of adherence in taking ARV FDC drugs and viral load. The chi-square test would be utilized if there were no cells with an expected value of less than five. In other words, cells with an expected value of less than five used a chi-square exact.

\section{RESULT}

In Table 1, it can be seen that the cross-tabs data are based on demographic characteristics and the adherence level in taking antiretroviral FDC
Table 1. Characteristics of Research Subjects

\begin{tabular}{|c|c|c|c|c|}
\hline \multirow[b]{2}{*}{ Variable } & \multicolumn{3}{|c|}{$\begin{array}{l}\text { Adherence Levels in } \\
\text { taking ARV FDC Drugs }\end{array}$} & \multirow[b]{2}{*}{$\mathrm{p}$} \\
\hline & $\begin{array}{l}\text { Good } \\
(>95 \%) \\
\mathrm{N}=56\end{array}$ & $\begin{array}{c}\text { Moderate } \\
(80-95 \%) \\
N=8\end{array}$ & $\begin{array}{r}\text { Poor } \\
(<80 \%) \\
\mathrm{N}=6\end{array}$ & \\
\hline \multicolumn{5}{|l|}{ Gender } \\
\hline Male & 94.6 & 87.5 & 100 & \multirow{2}{*}{0.593} \\
\hline Female & 5.3 & 12.5 & 0 & \\
\hline \multicolumn{5}{|l|}{ Age (y.o) } \\
\hline Late adolescence & 8.9 & 37.5 & 16.6 & \multirow{3}{*}{0.003} \\
\hline Early adulthood & 53.5 & 50.0 & 83.3 & \\
\hline Late adulthood & 37.5 & 12.5 & 0 & \\
\hline \multicolumn{5}{|l|}{ Education } \\
\hline Elementary school & 8.9 & 0 & 0 & \multirow{4}{*}{0.515} \\
\hline Middle School & 17.8 & 37.5 & 0 & \\
\hline High school & 57.1 & 62.5 & 100 & \\
\hline College/university & 16.0 & 0 & 0 & \\
\hline \multicolumn{5}{|l|}{ Occupation } \\
\hline Employed & 58.9 & 50.0 & 50.0 & \multirow{2}{*}{0.818} \\
\hline Unemployed & 41.0 & 50.0 & 33.3 & \\
\hline \multicolumn{5}{|l|}{ Marital status } \\
\hline Married & 42.8 & 37.5 & 16.6 & \multirow{3}{*}{0.688} \\
\hline Widower & 14.2 & 12.5 & 33.3 & \\
\hline Single & 42.8 & 50.0 & 50.0 & \\
\hline \multicolumn{5}{|l|}{ Risk factors * } \\
\hline Heterosexual & 33.9 & 50.0 & 50.0 & 0.543 \\
\hline Homosexual & 7.1 & 0 & 0 & 0.593 \\
\hline Injectable drug & 62.5 & 75.0 & 50.0 & 0.631 \\
\hline Free sex & 1.7 & 0 & 0 & 0.882 \\
\hline Piercing & 3.5 & 0 & 0 & 0.776 \\
\hline Tattoo & 3.5 & 0 & 0 & 0.776 \\
\hline
\end{tabular}

* Note: some research subjects have more than one risk factor

drugs. A total of 56 out of 70 (80\%) research subjects had good adherence (95\%). Based on gender, the majority of subjects were males with good, moderate, or poor levels of adherence. Meanwhile, based on age, the majority of subjects were early adulthood (26-35 years old), followed by late adulthood (36-45 years old) and late adolescence (17-25 years old). The educational background of the research subject started from high school with the most significant number of the subjects, followed by university level, junior high school, and elementary school. Most of the subjects were employers and unmarried with risk factors using injecting narcotics, psychotropic substances, or additives (NAPZA).

The result of the Kruskal-Wallis test showed there were no differences in the adherence level in taking ARV FDC drugs among the groups based on gender, education level, marital status, employment status, and risk factors for HIV infection ( $p>0.05)$. However, there were significant differences in the group based on age $(p=0.003)$. Table 1 shows that the subjects who were in a poor level of adherence in taking ARV FDC drugs ( $\leq 80 \%$ ) were mostly early adulthood (26-35 years). 


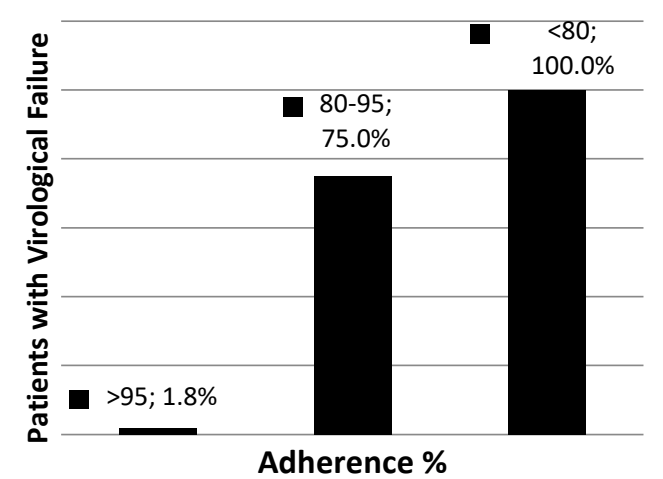

Figure 1. Virological Failure based on the Adherence Level toward ARV FDC Therapy

Table 2. The relationship between the adherence level in taking ARV FDC drugs and viral load

\begin{tabular}{|c|c|c|c|c|c|c|c|}
\hline \multirow{3}{*}{$\begin{array}{l}\text { Adherence in } \\
\text { taking ARV FDC } \\
\text { drugs }\end{array}$} & \multicolumn{4}{|c|}{ Viral Load } & \multirow{2}{*}{\multicolumn{2}{|c|}{ Total }} & \multirow{3}{*}{ P. } \\
\hline & \multicolumn{2}{|c|}{$\begin{array}{c}\leq 400 \\
\text { copies } \\
/ \mathrm{ml}\end{array}$} & \multicolumn{2}{|c|}{$\begin{array}{l}>400 \\
\text { copies/ } \\
\mathrm{ml}\end{array}$} & & & \\
\hline & $\mathrm{N}$ & $\%$ & $\mathrm{~N}$ & $\%$ & $\mathrm{~N}$ & $\%$ & \\
\hline Good (> 95\%) & 55 & 98.2 & 1 & 1.8 & 56 & 100 & \\
\hline Moderate (80-95\%) & 2 & 25.0 & 6 & 75 & 8 & 100 & 0.000 \\
\hline Poor $(<80 \%)$ & 0 & 0 & 6 & 100 & 6 & 100 & \\
\hline
\end{tabular}

In Figure 1, it can be seen that the adherence level in taking ARV FDC drugs influenced the percentage of virological failure ( viral load $>400$ copies $/ \mathrm{ml}$ ). The respondents with a good level of adherence ( $\geq 95 \%$ ) experienced virological failure of $1.8 \%$, which is far less compared to a moderate level (80-95\%) and poorlevel of adherence $(\leq 80 \%)$.

Table 2 shows the result of the exact Chisquare test, revealing the relationship between the level of adherence in taking ARV FDC drugs and viral load $(p=0.000)$.

\section{DISCUSSION}

Based on gender, out of 70, 66 (94.3\%) subjects were males. The result is in line with the data from the Indonesian Ministry of Health in $2012,{ }^{10}$ showing that males are more likely to live with HIV / AIDS than females by a ratio of 2:1. ${ }^{10}$ Another study showed $72.3 \%$ of 595 subjects with HIV / AIDS are males. ${ }^{12}$ The high proportion of males infected by HIV/ AIDS is assumed to be caused by a large number of males who commit risky sexual relationships and use injecting drugs. Meanwhile, females are more often infected with HIV from their sexual partners. It is supported by the result of research at $\mathrm{H}$. Adam Malik General Hospital Medan, which revealed that $73 \%$ of 163 research subjects were infected with HIV through a risky sexual relationship, the majority of whom are males. Furthermore, $77.6 \%$ of 58 subjects who were at risk of being infected with HIV through blood were males. ${ }^{13}$ Other studies also mention that males are more at risk of being infected with HIV / AIDS due to negative behaviors carried out, for example, using commercial sex services and injecting NAPZA. ${ }^{14}$

The highest prevalence of HIV / AIDS cases in Pengayoman Cipinang Hospital is in the group of early adulthood, and late adulthood (26-45 years) which is categorized as a productive age. The result of other studies also showed that the majority of people infected with HIV / AIDS were in the productive age range. ${ }^{15}$ In this study, it was also found that there were differences in the adherence level in taking ARV FDC drugs based on the age of the group members. Subjects with a low level of adherence in taking ARV FDC drugs ( $\leq 80 \%$ ) mostly belong to the group of early adulthood (26-35 years) (Table 1). Thus, the group needs to be given more attention through education and support from both medical personnel and families to increase their adherence level in taking medicine.

Based on the level of education, most subjects have the most recent High School education level. The result of other studies showed that the incidence of HIV / AIDS is more common in people who have a high level of education. ${ }^{12,14}$ In general, people with higher education have a better level of knowledge related to the problem of HIV / AIDS, so they are expected that they do not engage in risky behavior to become infected with HIV. However, the result of this study indicates that most subjects are highly educated. It is suspected that the social environment becomes the major factor of subjects with higher education levels infected with HIV. This assumption is supported by the result of the research showing that sexually transmitted infections, including HIV, more frequently occur in groups with high school education level and above. In that study, it was assumed that the increasing level of economic stability and higher education level have an impact on the growing use of prostitution services. ${ }^{16}$

The research subjects in this study are mostly employed. It is in line with other studies that found that HIV / AIDS infected subjects were patients who were employed. ${ }^{12} \mathrm{~A}$ person who works and has more income makes it possible to carry out risky behavior to be infected with HIV, primarily when an inadequate social environment influences it.

Based on marital status, this study revealed that most subjects are unmarried. Other studies have also found that people with unmarried status 
are at risk of being infected with HIV / AIDS. ${ }^{14}$ The riskiest factor for HIV / AIDS infection in this study was the use of drug injection. It is in line with data indicating that the current spread of HIV is not only through a sexual relationship, but also through drug injection identified to be able to transmit HIV of 50 $90 \% .^{10}$

The overview of virological failure by a total of 56 out of $70(80 \%)$ research subjects had good levels of adherence in taking ARV FDC drugs ( $\geq 95 \%)$ (Table 1). It is in line with studies suggesting that the simpler the ARV drug regimen is, the higher the level of the patients' adherence in taking ARV drugs will be. Patients with FDC were twice as much as adherence level in taking medication compared to those using multiple ARV regimens. ${ }^{4}$ The adherence to medication is a condition in which patients adhere to treatment based on their consciousness, not only due to their adherence to the doctor's command. ${ }^{3}$

Disadherence of patients in taking ARV drugs can result in therapy failure. In order to achieve a good virological suppression, a high level of adherence to ARV is highly needed. The result of this study showed that to achieve an optimal level of viral suppression, at least $95 \%$ of all medication doses must not be abandoned. The risk of therapy failure arises when the patient frequently ignores to take medication. Good collaboration between health workers and patients, as well as communication and constructive treatment atmosphere, will raise patients' adherence to take medication. ${ }^{3}$ Specifically, the result of this study shows that the subjects with a good level of adherence to ARV FDC medication ( $\geq 95 \%$ ) who experienced treatment failure are only $1.8 \%$ (Figure 1). It reveals the effectiveness of the mechanism of ARV FDC consisting of Tenofovir, lamivudine, and efavirenz to inhibit reverse transcriptase so that the viral RNA chain can not be altered into DNA. The similar result shows that the ARV FDC regimen plays an important role in the HIV suppression. HIV patients with good adherence tend to have undetectable viral load values. Besides, the result of this study also showed that the use of FDC ARV could reduce the risk of HIV patients being hospitalized by $31 \%$ and increase the opportunity of an undetectable viral load by $21 \% .{ }^{17}$

Criteria for the failure of antiretroviral therapy, according to WHO (2013), ${ }^{18}$ are determined by the amount of viral load by $>400$ copies $/ \mathrm{ml}$ upon oneyear therapy, or the viral load becomes redetectable after being undetected. The patients' noncompliance most likely causes the failure of therapy in taking $\mathrm{ARV} .{ }^{18}$ The result of this study reveals that the subjects with a moderate level of adherence (80-95\%) experienced treatment failure indicated by the virological failure of up to $75 \%$. Meanwhile, patients with a poor level of adherence ( $\leq 80 \%$ ) experienced a $100 \%$ treatment failure (Figure 1).

Furthermore, this study also found a relationship between the level of adherence to taking ARV FDC and viral load (Table 2). It is the most important factor in suppressing the number of HIV viruses. The long stable viral suppression aims to keep the body's immune system high. Thus, people infected with HIV will obtain a good quality of life and also prevent morbidity as well as mortality. ${ }^{6}$

In subjects with a good and moderate level of adherence, it is necessary to provide constant counseling regarding the adherence to taking ARV medicine. Based on the therapy guidelines, upon adherence counseling, the patient needs to be evaluated for three months while taking first-line ARVs. If a decrease in viral load reaches the target, the conduction of first-line ARVs will remain. Conversely, if there is an increase in viral load, the therapy is later switched to the second-line ARVs., ${ }^{6,19}$ The noncompliance to taking medication allows resistance due to mutation. The result of the study in HIV patients in West Java found resistance to first-line ARV medicine in subjects with virological failure (viral load $\geq 400$ copies $/ \mathrm{ml}$ ) upon 6-month therapy. ${ }^{12}$

In a similar study, virological failure was found in $21.7 \%$ of HIV patients with an adherence level of $\geq 95 \%, 80-95 \%$ of adherence level ranges from 54.6$66.7 \%$, and $<80 \%$ reaches $>71.4 \%{ }^{11}$ The difference between the result of that study and the result of this study can be caused by differences in the drug regimen used. The result of the study explained above used the protease inhibitors in therapy. ${ }^{11}$ Moreover, other possibilities are differences in the subtype, sub-sub types, or recombinant forms of HIV that infect the subject of the research and that the percentage of virological failure is also different despite a similar level of adherence in taking medication process. The research in East Java identifying 30 samples of HIV-1 subtypes showed that the subtypes found were mostly a group of Circulating Recombinant Forms similar to those found in Southeast Asia. ${ }^{20}$ Besides that, the virological failure is also known to be determined by an increase in CD4 levels. An increase in CD4 by $<50$ cells $/ \mathrm{mm}$ is an independent predictor of virological failure in HIV patients receiving the first-line ARV therapy with a good level of medication adherence. ${ }^{21}$ 
This study only utilized the data of medical records written in HIV Treatment Overview and Antiretroviral Therapy, so that there are undetected risk factors that are likely to influence the adherence level of ARV FDC, for example, the background of alcohol consumption of the research subjects. Besides, the medical record did not show the HIV subtype as a result of the GenXpert examination. Thus, it cannot be further analyzed whether differences in HIV subtypes also caused virological failure.

\section{CONCLUSION}

There was a significant relationship between the level of adherence in taking ARV FDC and viral load.

\section{REFERENCES}

1. Kemenkes, R. I. Laporan Perkembangan HIV-AIDS dan Penyakit Infeksi Menular Seksual (PMS) Triwulan I Tahun 2017. 2017. Accessed from: http://www.siha.depkes.go.id.

2. World Health Organization. Consolidated guidelines on the use of antiretroviral drugs for treating and preventing HIV infection: recommendations for a public health approach. Geneva: World Health Organization. 2016.

3. Kemenkes, R. I. Pedoman Nasional tatalaksana klinis infeksi HIV dan terapi antiretroviral pada orang dewasa. Kementrian Kesehatan Republik Indonesia. Jakarta. 2011.

4. Sutton, S. S., Ahuja, D., \& Magagnoli, J. What is the effect of pill burden on adherence to HIV antiretroviral therapy? Journal of the American Academy of PAs, 2016, 29(11), 16-17.

5. Djoerban, Z. \& Djauzi, S. HIV / AIDS di Indonesia. In: Setiati, S., Alwi, I., Sudoyo, A.W., Simadibrata, M., Setyohadi, B. \& Syam, A.F. (eds). Buku Ajar Ilmu Penyakit Dalam Jilid I. (pp. 803-891). Jakarta: Interna Publishing. 2014.

6. Karyadi, T. H. Keberhasilan Pengobatan Terapi Antiretroviral. Jurnal Penyakit Dalam Indonesia, 2017; 4 (1): 1-3.

7. Mylonakis, E., Paliou, M., \& Rich, J. D. Plasma viral load testing in the management of HIV infection. American family physician, 2001; 63(3): 483.

8. Astari, L., Sawitri, S. Y., \& Hinda, D. Viral Load pada infeksi HIV. Berkala Ilmu Kesehatan Kulit dan Kelamin, 2009; 21 (1): 31-8.

9. World Health Organization. WHO prequalification of in vitro diagnostics public report. World Health Organization, Geneva, Switzerland. 2017.

10. Kementerian Kesehatan Republik Indonesia.
2012. Perkembangan HIV-AIDS di Indonesia Triwulan III Tahun 2012, (Article Online), retrivied from (http://www.depkes.go.id/article/print/2186/ perkembangan-hiv-aids-di-indonesia-triwulan-iiitahun-2012.html, accessed 2 February 2019).

11. Paterson, D. L., Swindells, S., Mohr, J., Brester, M., Vergis, E. N., Squier, C., ... \& Singh, N. Adherence to protease inhibitor therapy and outcomes in patients with HIV infection. Annals of internal medicine, 2000; 133 (1): 21-30.

12. Fibriani, A., Wisaksana, R., Indrati, A., Hartantri, Y., van de Vijver, D., Schutten, M., ... \& van der Ven, A. Virological failure and drug resistance during first line anti-retroviral treatment in Indonesia. Journal of medical virology, 2013; 85 (8): 1394-1401.

13. Rangkuti, A. Y., \& Sarumpaet, S. M. Karakteristik Penderita Aids Dan Infeksi Opurtunistik Di Rumah Sakit Umum Pusat (RSUP) H. Adam Malik Medan Tahun 2012. Gizi, Kesehatan Reproduksi dan Epidemiologi, 2013; 2 (5).

14. Umam, H., Dewi, Y. I., \& Elita, V. Identifikasi karakteristik orang risiko tinggi HIV dan AIDS tentang program pelayanan voluntary counseling and testing (VCT). Jom, 2015; 2(1): 853-862.

15. Peraturan Menteri Kesehatan Republik Indonesia Nomor 87 Tahun 2014 tentang Pedoman Pengobatan Antiretrovial.

16. Karim, Q. A., \& Humphries, H. reducing HIV Infection in Young Women in Southern Africa: the Key to Altering epidemic trajectories in a generalized, Hyperendemic Setting. Medicine (Baltimore)[Internet], 2018; 1-7.

17. Rangarajan, S., Colby, D. J., Le Truong Giang, D. D. B., Nguyen, H. H., Tou, P. B., Danh, T. T., ... \& Nguyen, N. Q. Factors associated with HIV viral load suppression on antiretroviral therapy in Vietnam. Journal of virus eradication, 2016; 2 (2): 94.

18. Volberding, P., Greene, W., Lange, J. M., Gallant, J. E., \& Sewankambo, N. Sande's HIV/AIDS medicine: medical management of AIDS 2013. Elsevier Health Sciences. 2012.

19. Permenkes, R. I. Pedoman Pengobatan Antiretroviral. Peraturan Menteri Kesehatan Republik Indonesia (Permenkes RI) Nomor, 87. 2014.

20. Ismail, Y., Soetjipto, S., Wasito, E., \& Nasronudin, N. Analysis of HIV Subtypes and Clinical Staging of HIV Disease/AIDS in East Java. Indonesian Journal of Tropical and Infectious Disease, 2012; 3 (2): 76-82.

21. Kurniawan, F., Djauzi, S., Yunihastuti, E., \& Nugroho, P. Faktor Prediktor Kegagalan Virologis pada Pasien HIV yang Mendapat Terapi ARV Lini Pertama dengan Kepatuhan Berobat Baik. Jurnal Penyakit Dalam Indonesia, 2017; 4(1): 29-34. 